\title{
HOMESCHOOLING: AN ALTERNATIVE TO NEW NORMAL ADAPTATION OF LEARNING
}

\author{
Eka Damayanti', Eva Meizara Puspita Dewi², Novita Maulidya Jalal ${ }^{3}$, Nurfajriyanti Rasyid ${ }^{4}$, \\ Nurhaerani Haeba ${ }^{5}$ \\ ${ }^{1}$ Universitas Islam Negeri Alauddin Makassar, 2,3,4 Universitas Negeri Makassar, ${ }^{5}$ Department of \\ Education and Culture of Southeast Sulawesi \\ 1,2,3,4Makassar, Indonesia, ${ }^{5}$ Kendari, Indonesia \\ Email: eka.damayanti@uin-alauddin.ac.id ${ }^{1}$, evabasti@yahoo.com², \\ novitamaulidyajalal@unm.ac.id ${ }^{3}$, nurfajryantirasyid@gmail.com ${ }^{4}$, nurhaeranihaeba@gmail.com ${ }^{5}$,
}

\begin{abstract}
:
This research aims at finding out the public perception about the homeschooling which is chosen as an alternative in adaptation to the new normal learning. This research took forty-eight participants who are dominated by educators and magister or profession. Questionnaire as the instrument on this research was shared via google form. The collected data were analyzed by using descriptive statistics. The findings show that the participants think about the theme "Homeschooling: An Alternative to New Normal Adaptation of Learning" in workshop activities suitable with the conditions of the covid-19 pandemic and fulfill the participants' needs. The previous studies show that many things should be considered by looking at the advantages and risks of applying homeschooling, which means that other alternatives such as pleasant activities can be applied during the new normal.
\end{abstract}

\begin{abstract}
Abstrak:
Penelitian ini bertujuan untuk mengetahui persepsi masyarakat tentang homeschooling yang dipilih sebagai alternatif dalam adaptasi terhadap pembelajaran normal baru. Penelitian ini mengambil empat puluh delapan partisipan yang didominasi oleh tenaga pendidik dan magister atau profesi. Angket sebagai instrumen dalam penelitian ini dibagikan melalui formulir google. Data yang terkumpul dianalisis dengan menggunakan statistik deskriptif. Temuan menunjukkan bahwa peserta memikirkan tema "Homeschooling: Sebuah Alternatif Pembelajaran Adaptasi Normal Baru" dalam kegiatan lokakarya yang sesuai dengan kondisi pandemi Covid19 dan memenuhi kebutuhan peserta. Studi sebelumnya menunjukkan bahwa banyak hal yang harus diperhatikan dengan melihat keuntungan dan risiko penerapan homeschooling, yang artinya alternatif lain seperti aktivitas menyenangkan dapat diterapkan pada saat baru normal.
\end{abstract}

\section{Keywords: \\ Adaptation, Homeschooling, New Normal}

How to Cite: Damayanti, E., Dewi, E. M. P., Jalal, N. M., Rasyid, N., \& Haeba, N. (2020). Homeschooling: An Alternative to New Normal Adaptation of Learning. Lentera Pendidikan : Jurnal Ilmu Tarbiyah dan Keguruan, 23(2), 271-284. https://doi.org/10.24252/lp.2020v23n2i7.

\section{INTRODUCTION}

World Health Organization (WHO, 2020) shown that the number of COVID-19 patients in the world until Tuesday, July 21 st 2020 is about 14.562 .550 cases of COVID-19 
which confirmed with the number of patients who died about 607.781 people. The number of COVID-19 positive patients in Indonesia due to the data from COVID-19 infographic (2020) about 89.869 confirmed cases, the number of patients recovered about 48.466 people and the number of patients died is about 4.320 which spread across thirty-four provinces and 469 districts/cities, which indicate that there are 1.655 new cases in the last 24 hours. South Sulawesi has 8.257 cases which become the third most COVID-19 positive province in Indonesia after East Java and DKI Jakarta (Kompas.Com, 2020).

COVID-19 pandemic has spread fidgety in all the world and any efforts have been done to recover and struggle to unspread this virus. All activities and work are disrupted. United Nations Educational, Scientific and Cultural Organization (UNESCO) found that there are at least 290.5 million students in the worldwide whose learning activities have become disrupted due to the closed schools (Purwanto, Pramono, Asbari, Hyun, Wijayanti, Putri, \& Santoso, 2020). Muhammad Tito Karnivan (the Minister of Indonesia Internal Affairs) issued a new normal rule facing COVID-19. The rule is set out in the Decree of the Minister of Internal Affairs No. 440-830/2020 which is about guidelines to the New Normal Order of Productive and Safe Corona Virus Disease 2019 for the State Civil Servant among the domain of the Ministry of Internal Affairs and Local Government. That rules explain that the community/people can already carry out normal activities as usual but they must still implement health protocols and some areas which want to apply new normal must meet the requirements set out in the Ministry of Foreign Affairs rules (Kemendag, 2020). Referring to the government regulations due to the implementation of new normal should pay attention to several things: (1) keep physical distance; (2) using masks/Personal protective equipment (PPE); (3) live a clean lifestyle; (4) avoid touching objects; and (5) always be outdoors.

The government tried various efforts to prevent this virus such as establishing lockdown policy of closing cross-region interactions till the new normal (a new lifestyle) with condition of still implementing health protocols. Rumba (2020) argued that 'New Normal' is a normal phase on pandemic condition that means that people continue to live their lives normally but they must apply health protocols in their daily activities. New normal conditions provide changes such as the campus promotion, human resource management, and handling other academic activities. Muhyiddin (2020) believed that new normal has a socio-economic impact on the society due to the prolonged pandemic. Lumbanraja (2020) also stated that the implementation of new normal also has an impact on the credibility of public services. The implementation of these policies causes the people unable to interact directly among them.

At the education level, the implementation of new normal has an impact on the educators, especially to the school principal. The school principal plays important role in providing educational services and other stimulation to the students. Learning activities in the schools continue to undergo health protocols to prevent the spread of COVID-19. The teachers are responsible for the school environment and the students comfortable and discipline. The teachers, students, and parents should feel comfortable. Hazizah (2020) 
argued that optimizing all components of education can carry out the learning process effectively in different atmospheres.

Homeschooling as the learning process alternative can be implemented at home during COVID-19 pandemic. Homeschooling becomes a common interest as one of the alternative educational models. Safar (2018) revealed that the existence of homeschooling is expanding in accordance with the easy way of getting information from various digital media due to the new digital era which demand all children to study at home during pandemic that causes everyone chooses alternative models as the best educational solution.

In the times of this obscurity outbreak, education is urgently needed for the country which means that education must always run properly in any condition. The government issued policies such as home learning at home in order to keep education in Indonesia run properly. One of the appropriate methods used during this pandemic is the homeschooling method. Sari (2020) defined homeschooling as one of the important choice and the role of family can be one way of solving the educational problem. Staying at home can be used to sharpen the role of parents as the children's primary educator, especially their competency standards in the children's learning process as well as formal, informal and nonformal learning.

Mariana (2019) asserted that homeschooling becomes an educational platform that provides the widest opportunities to children to develop themselves. They can choose the best access (digital access) to meet their needs of the educational materials. Santoso (2010) argued that homeschooling means the self-reliance aspect in organizing education in the family environment. Sumardiono (2007) defined homeschooling as the model of education in which the family must take responsibility for their children's education by using home as its educational base. It means that the parents are directly involved in determining the children's education process, the determination of educational direction and objectives, the values to be developed, intelligence and skills, curriculum and materials as well as learning methods and practices. Edy (2013) argued that homeschooling is a home learning activity, but homeschooling does not mean moving the school curriculum to home. In line with Fitriana (2016), she believed that homeschooling is a flexible and varied educational program option as the reflection of human diversity in choosing the method used and the children still learn the same materials as in the public schools but the schedule of education programs is determined from their interest and readiness.

Heryani (2017) described homeschooling as a model of home-based education with the parents who are responsible and focuses on the interests and their children's needs. In its development, the parents can work with other agencies to facilitate the homeschooling process by joining the homeschooling community. Hanaco (2012) defined the daily homeschooling as commonly interpreted as "school at home". The important thing that underlies homeschooling is that the education conducted by the family should focus on the interests and needs of the children, which aims at developing all children potential. Kembara (2007) reveals that homeschooling is a worth alternative concept that is implemented to give everyone the option of mastering knowledge due to their own style. 
Homeschooling has several strengths and weaknesses. Wardati (2019) argued that the strengths of homeschooling are: (1) Adjusted to the condition and needs of the students; (2) Adjusted to the interests of the students; (3) Adjusted to the family conditions; (4) Opening up a wide opportunity to be independent and creative; (5) Avoiding various patterns due to miss-association; (6) Being ready to be involved into the real world because they are accustomed to join learning process based on their daily activities; (7) Completing the education in less time; (8) Customized with pockets; and (9) customizable the study time. Saputra (2007) also argued that the strengths of homeschooling are: (1) Giving more self-reliance/confidence and creativity for the students; (2) Getting more opportunity to achieve individual in maximum competencies; (3) The protection from social diseases such as drugs, consumerism, deviant associations and fighting; and (4) Enabling children to be prepared for real life with a wider scope of association. Adilistiono (2010) added the points of view about the strengths of homeschooling such as: (1) Promoting individual self-reliance/confidence and creativity instead of classical learning; (2) Providing opportunities to achieve individual competencies fully; and (3) Protected from fighting, delinquency, store association, and consumerism.

Wardati (2019) revealed that the weaknesses of homeschooling are: (1) Demanding on high discipline and commitment; (2) Being difficult to measure a student's ability due to the absence of a competitive atmosphere so that the student does not compete with his friends; (3) Complex responsibilities in parents; and (4) Lack of interaction between the students and their friends. Saputra (2007) defined that there are several weaknesses of homeschooling namely: (1) The difficulty of obtaining support or someone to ask; (2) Lacking of socialization places and lacking of skilled parents who cannot facilitate the learning process; and (3) Evaluating and its equivalence. Adilistiono (2010) argued that the weaknesses of homeschooling such as: (1) The children who study in homeschooling have less interaction with and their peers; (2) The school is a typical learning place that can train children to compete and achieve the highest success; (3) Homeschooling can isolate learners from unpleasant realities; and (4) If the child is only studying in homeschooling it is likely isolated from the social environment.

Homeschooling grows rapidly due to the cause of many factors including outstanding development of information technology. The exploration of quality learning materials such as literature, journals, and books, scientific discussion forums, and consultations with world experts, can be done easily without experiencing restrictions because each individual does it himself. Besides that, there are also homeschooling factors namely: (1) Failure of formal school, both in America and Indonesia, the failure of formal schools in producing better quality education is the originator for families in Indonesia and go abroad in order to conduct homeschooling; (2) Diversity of intelligence, one of the influential theories in the development of homeschooling is multiple intelligence or intelligence diversity theory; (3) Homeschooling figures, many important world figures get successful in their life without going to formal school also create the emergence of homeschooling; and (4) Facilities and infrastructure, the development of homeschooling is also generated by facilities that are developing in the real world (Afiat, 2019). 
Ariefanto (2017) expressed that the factors the parents divert their children to homeschooling namely: (1) the disappointment towards school due to the attitudes and pressures of teachers and friends in school that make children less comfortable which causes them to choose homeschooling; and (2) the parents are worried about their children from negative environments and parental dissatisfaction with the formal school system. Moreover, Zulfi (2019) also assumed that some factors affected the rise of homeschooling are: (1) parental distrust of formal schools due to the curriculum is constantly changing; (2) parental dissatisfaction with the current education system, especially with the exam system; (3) the parents think that the children have a lot of homework daily and become pressured about it; (4) the parents are worried about their children becoming the victims of unhealthy environments; and (5) the children feels burdened with the rules applied in the formal school.

Lot of discussion and disputation about the learning needs at home during the COVID-19 pandemic with the strengths and weaknesses of homeschooling, then this research was conducted to provide a theoretical affirmation of the review in accordance with the perspectives of the parents, educators, and students.

\section{RESEARCH METHOD}

This research is named as a devotional research which is conducted by the Educational Psychology Association of Indonesia (APPI) of Sulawesi region. The researchers provided intervention in workshop activities form with the theme "Designing Homeschooling Activities for the Adaptation of New Normal in Learning" which was conducted on July 5th, 2020 through Zoom meeting room. The number of participants involved in this devotional research was about forty-eight people who were dominated from educator backgrounds.

Table 1. Participant's Professional Background and Education Level

\begin{tabular}{lr}
\hline Profession Types & Percentage \\
\hline Teacher/Lecturer/Educator & 68.8 \\
Students & 10.4 \\
Others & 20.8 \\
\hline Total & $\mathbf{1 0 0}$ \\
\hline & \\
\hline Education Level & Percentage \\
\hline Doctoral S3 & 6.25 \\
Master's Degree S2 & 79.17 \\
Bachelor S1 & 6.25 \\
Senior High School/ The Same Level & 8.3 \\
\hline Total & $\mathbf{1 0 0}$ \\
\hline
\end{tabular}

Those participants have heterogeneous current educations that are dominated by the profession of Master's Degree S2. The instrument in the data collection used a questionnaire which was shared among the participants through Google form. The collected data were analyzed using descriptive statistics. 


\section{RESULTS AND DISCUSSION}

\section{Designing Homeschooling Activities as a Need for the New Normal Adaptation in Learning}

The participants think that the theme "Designing Homeschooling Activities for the New Normal Adaptation in Learning" in workshop activities is appropriate with COVID-19 pandemic conditions (See Figure 1). Moreover, the theme in the workshop activities agrees with the needs of the participants (See Figure 2). The parents start thinking about the best conditions for their children to get an education without going to the school. One of them is educating children through Homeschooling, because Homeschooling has its own fraction for parents and educators.

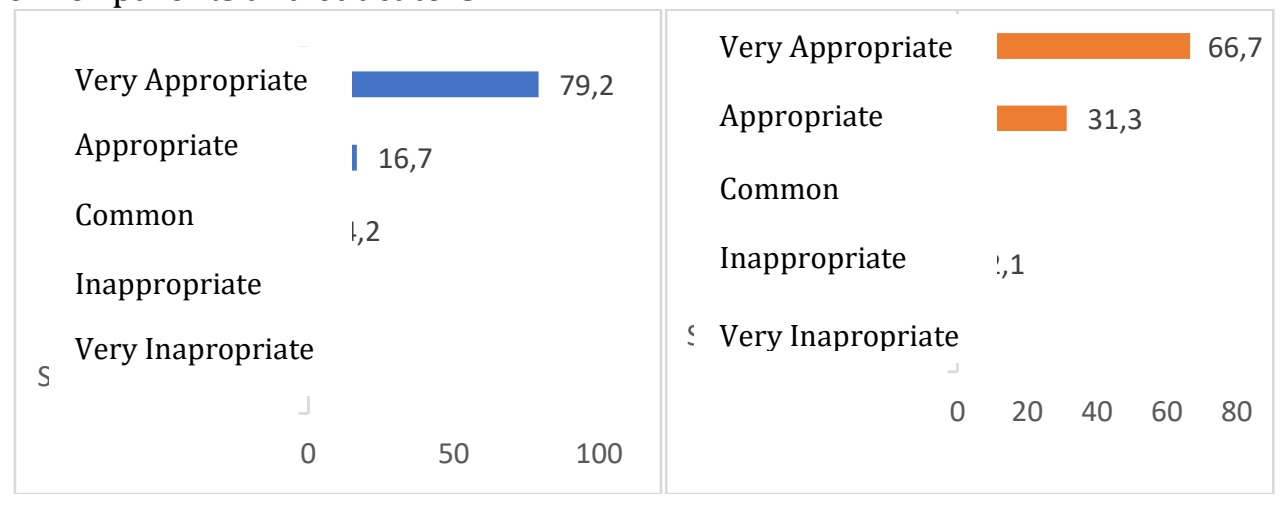

Figure1. Homeschooling based on pandemic conditions
Figure2. Homeschooling based on the participants' needs

Sumardiono (2007) stated that homeschooling has a principle in education which means that a family is responsible for their children's education and use home as educational base. The parents are responsible and directly involve in the process of arranging education and PDCA (Plan, Do, Check and Actions) by determining the direction and objectives of education, the values, the skills and abilities that need to be achieved, and the learning curriculum till the way of children's learning in their daily life. Those principles are in line with the current condition of parents who increasingly play important role in helping their children's education during studying from home (SFH). Those principles are in line with the research which was conducted by the Nation Household Education Survey Program (NHES) in 2003 (Kembara, 2007) who obtained the data about the parents' reasons for doing Homeschooling, it was shown that $31 \%$ of parents expressed concern about the formal school environment, 30\% of parents were closer to provide moral and religious education, and $16 \%$ of parents were dissatisfied with the formal school system.

The findings of the survey conducted by the researchers of Nutrition and Public Health Department at Semarang State University show that the online learning runs less effectively because it spends internet costs, it has lot of assignments, and it makes tired because someone must be in front of laptops and mobile phones continuously. Huebner \& Mc Cullough (2000) argued that uncomfortable experience at school can be a significant source of stress and reduce life quality for the students. Thus, not all students feel 
comfortable by online learning when they study from home virtually. The unmet needs of the students due to limited time and full of materials, lack of the students' skill development in nonacademic domain because the students are unable to use school facilities to develop them virtually. Some above problems have good reason to make the parents seek alternative education (which is free from those problem), which causes the parents school their children at home. Homeschooling becomes an alternative option for the parents to improve their children's education quality as well as get a pleasant learning atmosphere.

\section{Measuring the Existence of Homeschooling in New Normal Adaptations of Learning}

Homeschooling is a phenomenal alternative education model that is much discussed among the community, parents, and educational practitioners which is related to the socialization of children if they study at home. The parents are responsible and directly involve in education process. Homeschooling development in Indonesia occurred as a result of the parents' distrust toward formal schools because the curriculum is constantly changing (curriculum changing periodically) and burdens some students and makes them become the objects not subjects, hampering the students' creativity and intelligence in emotional, moral, and spiritual aspects. The parents also concern about the negative external environment and parental dissatisfaction with the formal school system. It is proven on the research conducted by the Nation Household Education Survey Program (NHES) in 2003 Kembara (2007: 43-44) that found the data on the parents' reasons for joining Homeschooling in the United States, it was found that $31 \%$ of the parents expressed concern about the formal school environment; $30 \%$ of the parents were consistent providing moral and religious education; and $16 \%$ of the parents were dissatisfied with the formal school system.

However, homeschooling also has a negative impact due to some research study, which revealed some weaknesses of homeschooling. Who examined 3 homeschooling students revealed the problems felt by the children related to their cognition in learning. He assumed that homeschooling is a boring learning place in accordance with same routine. The students believed that some lessons require special concentration and attention. Some students still felt afraid and ashamed to express their opinions and conveyed problems to their parents which hampered their communication in lesson. In addition, the social problems were felt by them because the relationships with their friends were limited due to the different learning activities, so the intensity of the meeting becomes ineffective.

Sumardiono (2007) mentioned that one of the weaknesses of homeschooling is that it has lower horizontal socialization. Home-schooling students are relatively unexposed to heterogeneous and it is isolated from social environments, especially for single home scholars. Moreover, it is also worried that the students may lose their opportunity to get along with a heterogeneous environment because the students can learn many things from that. The students will have less experience in social field, and decrease their sensitivity and competence, and less societal in adulthood. It is different from learning at school. 
Rachman (2007) believed that this school category cannot be applied regularly because it can damage the growth of children.

Savitri (2020), the homeschooling expert, explained in details about the strengths and weaknesses when they choose an education with a homeschooling system. The strengths of homeschooling, such as: (1) Customized education, the parents can compose their own curriculum and choose the lesson materials and learning styles based on their children's or potential; (2) Mature the independence and creativity of the child; (3) Cheap price and flexible, time and learning model; (4) It can develop children's potential early due to the learning activities can be done in any time; (5) Potential is easier to find out because it focuses on one child; (6) It is adaptable and it can apply a theory in the real practice because the learning activities are based on the students' daily lives; (7) It is easier to apply family values and principles because they spend more time together with their family; (8) It can deepen the parent-child relationships that the psychological aspects grow well; (9) It can avoid the adverse effects of school environment such as bullying, cheating, fighting, pornography, drug abuse, consumptive habits or fast-food; (10) Cross-age socialization occurs because it is not just hanging out among peers. Many opinions appeared about homeschooling that children will get difficulty to socialize. It is actually not true statement due to the fact that children can improve their cross-age socialization skills well; (11) The tuition fees are controlled and manageable allocated; (12) It is easy to grow the students' confidence because there is no chance of comparing among them in school; and (13) Intrapersonal capabilities are more developed, understand themselves, their purpose of life and their role in the world.

Furthermore, Savitri (2020) revealed some weaknesses of Homeschooling, such as: (1) it demands total parental responsibility and their involvement; (2) the students have less social skills among peers; (3) Lack of understanding of the competition process; (4) risk of having difficulty in team-work; (5) Parents must be ready to learn all times in order to deal with their complexity role; (6) Lack of learning facilities which are only intended for the formal schools; (7) homeschooling learning process may be interrupted, if there some problems occur such as parental divorce or death, and (8) get less support and motivation from other because homeschooling has not main option of learning.

Based on the analysis, it shows that a lot of considerations appeared by looking at the strengths and weaknesses of homeschooling. Thus, the children who join homeschooling will differ in output with children who join the formal school. Here are the principle differences between Homeschooling and Formal Schools:

Table 2. Homeschooling's Differences with Formal Schools

Home Schooling $\quad$ Formal School 
a. The parents become the main responsible person about their children's education.

b. The system hampers the children's needs and the family condition.

c. Learning schedule is flexible and it depends on child and family agreement.

d. Decentralized management is based on the wishes of homeschooling families.

e. Curriculum and teaching materials are selected and determined by the parents. a. The teachers and school managers are responsible for the students.

b. The standardization system of the children's needs is generally likened.

c. The schedule has been determined for all students.

d. Management is centralized at schools.

e. Curriculum and teaching materials are determined by the school.

Based on the above explanation, the researchers conclude that homeschooling is lacking of cooperative ability in completing school assignments, confronting and resolving social conflicts among the students' classmates even between classes, and their potential in leadership is not tested. The point is that the social competencies of homeschooling children cannot develop optimally because the children only focus on their own abilities. Homeschooling means moving all school potential to home. This means that all potential that exists in the children can be developed and taught at home. Homeschooling is the same as Home Education which is an education conducted independently by the family and the materials are selected and adapted by their needs.

Some parents are confused to choose the best learning method for their children due to the fact that many choices of educational pathways in Indonesia. The society really need a lot of clear and detailed information about the education types in order to be wise in choosing and meeting their parents' ability to guide their children to complete their studies properly. Homeschooling workshop activities that have been held show the material contents in designing homeschooling activities are beneficial for participants for alternative solutions in new normal adaptation. The following is the chart overview:



Figure3.The Benefits of Workshop Materials in Participants' Personal Lives and Professions

\section{Designing Home Learning Pleasurably}

There are four things to do in order to reconsider the strengths and weaknesses of homeschooling by doing learning at home pleasurably, namely: 
1. Setting the students' goals, visions, and needs

Hanna (2012) argued that in designing learning process at home, one of the things that the parents should need to concern establishing a curriculum that suits with the students' needs. The curriculum applied should be creative power of the parents by selecting teaching materials and learning processes based on the students' needs. Loy Kho in Nurfitriani (2007) defined that the curriculum that is most suitable for the students is "a curriculum that contains the most important priority for the students at their ages, which refers to the suitability between the students' talents, interests, abilities, and learning styles.

\section{Collecting available resources}

Sumardiono in Nurfitriani (2007) stated that using textbooks and teaching materials can be used in homeschooling process limitless. The learning process is not only limited in teaching-learning process by using books but it can also utilize daily activities for the learning process such as about the sense, attitude, or skill.

\section{Creating methods, designs, and learning processes}

Clements (2002) argued that most decisions about teaching methods used for homeschooling are related to the actual time of the parents planning used in learning process or learning activities, such as self-study or doing research projects. Furthermore, he revealed that in compiling the methods and design of learning process, the parents should consider the characteristics of their child. The research conducted by Gann \& Carpenter (2017) also assumed that the parents use a variety of teaching learning strategies including individual instruction, defense understanding, self-study, collaboration among their peers and adults as well as the application and connection of information as one method of arranging learning at home.

\section{Virtual game}

Tuzun, Soylu, Karakus, Inal, \& Kizilkaya (2009) in their research found that the application of computer games toward the students' geography in learning at elementary school significantly increased especially the students' learning motivation through games as a learning method. Vlacopoulos \& Makri (2017) in their research argued that there is a positive impact on learning through game methods and simulations. Games and simulations can increase motivation and provide students the opportunity to actively experience, practice, interact and reflect collaboratively of what they learn.

\section{Form of Participants' Application toward the Materials}

The effectiveness of this workshop can be seen from the evaluation of participants' understanding level that experienced improvement before the material was delivered to participants and after the material was delivered to the participants. Before the material was delivered, many participants did not understand and after the material was delivered, many participants began to understand and they deeply understand the material.

Deeply Not Understand Not Understand Just Same Understand $\quad$ Deeply Understand 


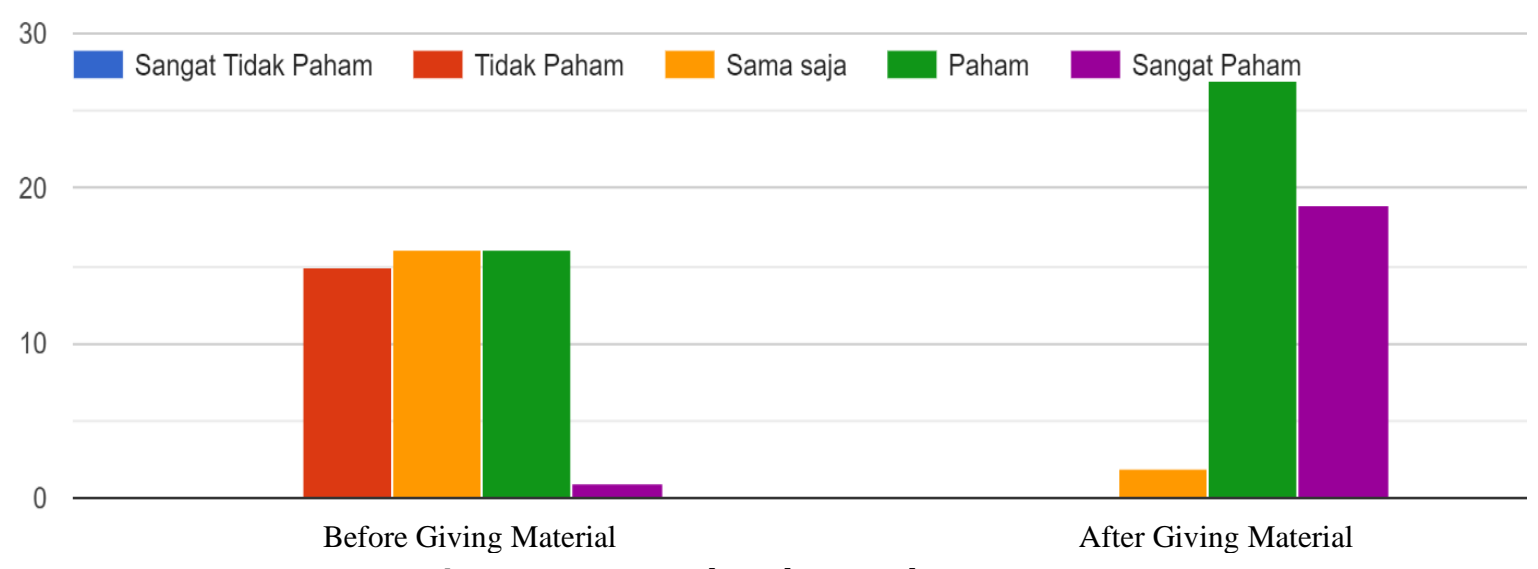

Figure 4. Material Understanding

The feedback after joining the workshop can be seen from following conclusion results of the participant's attitude towards the material that has been obtained along the workshop, they are: (a) Providing socialization to the community; (b) Applying home learning strategies to families and their environment; (c) Adding variations in SFH and WFH activities; (d) Being able to improve the learning experience; (e) Designing modules that suitable for home learning; (f) Trying to apply the strategies due to the conditions when the child uses Remote Education; (g) Creating homeschooling based on home learning; (h) Creating fun learning system at home; (i) Doing virtual games, and designing home learning curriculum; and (j) Compounding formal education and Homeschooling system for the children at home.

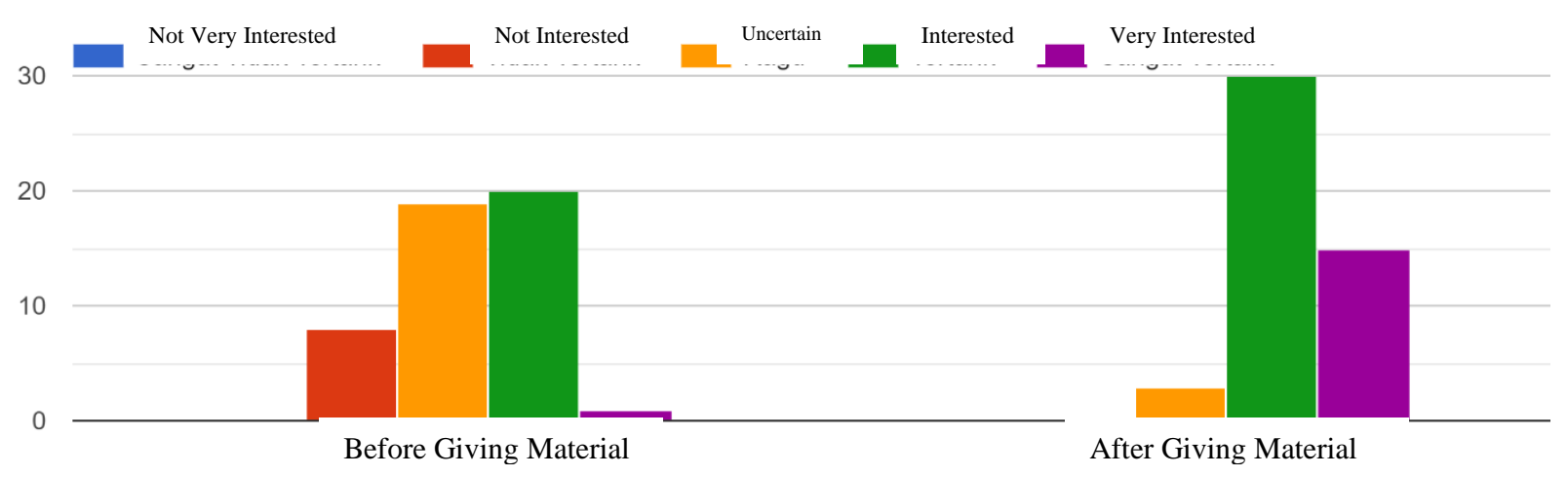

Figure 5.The Interest in Applying or Informing Home Learning to Others

\section{CONCLUSION}

The participants think that the theme "Designing Homeschooling Activities for the New Normal Adaptation in Learning" in workshop activities is appropriate with COVID-19 pandemic conditions. Moreover, the theme in the workshop activities agrees with the needs of the participants. The parents start thinking about the best conditions for their children to get an education without going to school. One of them is educating children through Homeschooling, because Homeschooling has its own fraction for parents and educators. Based on the findings of previous research, many things should be considered by looking at the strengths and weaknesses of applying homeschooling. 
The researchers conclude that homeschooling is lacking of cooperative ability in completing the school assignments, confronting and resolving social conflicts among their classmates even among the classes, and their potential in leadership not tested. The point is that the social competencies of homeschooling children cannot develop optimally because the children only focus on their own abilities. Homeschooling means moving all school potential to home. This means that all potential that exists in the child can be developed and taught at home. In the new normal period, considering the strengths and weaknesses of homeschooling by doing learning at home pleasurably: namely (1) Setting children's goals, vision and their needs; (2) Collecting available resort resources; (3) Creating methods, designs and learning processes; and (4) Virtual games.

\section{REFERENCES}

Adilistiono. (2010). Homeschooling Sebagai Alternatif Pendidikan. Jurnal Pengembangan Humaniora, 10 (1). https://www.google.com/search?q=Homeschooling+Sebagai+Alternatif+Pendidi kan\&oq=Homeschooling+Sebagai+Alternatif + Pendidikan\&aqs=chrome.0.69i59j0 i33312j69i60l2j69i61.1060j0j4\&sourceid=chrome\&ie=UTF-8.

Afiat, Z. (2019). Homeschooling; Pendidikan Alternatif Di Indonesia. Visipena Jurnal, 10(1), 50-65. file:///C:/Users/PC/Downloads/490-Article Text-863-1-1020200313.pdf.

Ariefanto, L. (2017). Homeschooling: Persepsi, Latar Belakang dan Problematikanya (Studi Kasus pada Peserta Didik di Homeschooling Kabupaten Jember). Jurnal Edukasi, 4(2), 21-26. http://repository.unej.ac.id/handle/123456789/91843.

Clements, A. D. (2002). Variety of teaching methodologies used homeschoolers: Case studies of three homeschooling families. ERIC. https://eric.ed.gov/?id=ED468436.

Edy, A. (2013). Ayah Edy Punya Cerita. Jakarta: Naura Books.

Fitriana, A. (2016). Efektivitas Pelaksanaan Pendidikan Homeschooling Sebagai Pendidikan Alternatif Dalam Mengembangkan Potensi Anak Di Homeschooling Kak Seto Jakarta Selatan. Jurnal Eksistensi Pendidikan Luar Sekolah (E-Plus), 1(1), 50-59. https://jurnal.untirta.ac.id/index.php/E-Plus/article/view/1182/946.

Gann, C., \& Carpenter. (2017). STEM Teaching and Learning Stategies of High School Parents With Homeschool Student. Journal of Education and Urban Society. https://doi.org/https://doi.org/10.1177/0013124517713250.

Hanaco, I. (2012). I Love Homeschooling: Segala Sesuatu Yang Harus Diketahui Tentang Homeschooling. Jakarta: Gramedia Pustaka Utama.

Hanna, L. G. (2012). Homeschooling education: Longitudinal Study of Methods, Material and Curricula. Education and Urban Society, 44(5), 609-631. https://eric.ed.gov/?id=EJ974745.

Hazizah, N. (2020). Leadership Headmaster In Improving The Quality Of Paud In The New Normal Period. Jurnal Pendidikan Luar Sekolah, 8(2), 143-146. https://doi.org/https://doi.org/10.24036/spektrumpls.v8i2.109155.

Heryani, R. D. (2017). Homeschooling Sebagai Sekolah Alternatif Ramah Anak. Research and Development Journal of Education, 3(2), 145-153. 
https://doi.org/http://dx.doi.org/10.30998/rdje.v3i2.2011.

Huebner, S. E., \& Mc Cullough, G. (2000). Correlates of school satisfaction among adolescents. The Journal of Educational Research, 93(5). https://doi.org/https://doi.org/10.1080/00220670009598725.

Kembara, M. (2007). Panduan Lengkap Homeschooling. Bandung: Progresio.

Kemendag. (2020). Aturan tersebut tertuang dalam Keputusan Menteri Dalam Negeri Nomor 440-830 Tahun 2020 tentang Pedoman Tatanan Normal Baru Produktif dan Aman Corona Virus Disease 2019 bagi Aparatur Sipil Negara di Lingkungan Kementerian Dalam Negeri dan Pemerintah Daerah. https://covid19.go.id/p/protokol/keputusan-menteri-dalam-negeri-nomor-440830-tahun-2020.

Kompas.Com. (2020). Update: Bertambah 1.655, Kini Ada 89.869 Kasus Covid-19 di Indonesia. Online. Diakses Pada 21 Juli 2020.

Lumbanraja, A. D. (2020). Urgensi Transformasi Pelayanan Publik Melalui E-Government Pada New Normal Dan Reformasi Regulasi Birokrasi. Administrative Law \& Governance Journal, 3(1), 220-231. https://doi.org/https://doi.org/10.14710/alj.v3i2.220-231.

Mariana, N. (2019). Pengembangan Kecerdasan Spiritual Anak Usia Dini Melalui Homeschooling. Jurnal Tarbiyah Al-Aulad, 4(1), 27-44. https://risetiaid.net/index.php/TA/article/view/416.

Muhyiddin. (2020). Covid-19, New Normal, dan Perencanaan Pembangunan di Indonesia. The Indonesia Journal of Development Planning, 4(2), 240-252. https://doi.org/https://doi.org/10.36574/jpp.v4i2.118.

Nurfitriani. (2007). Pelaksanaan Pembelajaran Pada Komunitas Homeschooling Kak Seto Pusat Tingkat SMA. UIN Syarif Hidayatullah.

Purwanto, A., Pramono, R., Asbari, M., Hyun, C. C., Wijayanti, L. M., Putri, R. S., \& Santoso, P. B. (2020). Studi Eksploratif Dampak Pandemi COVID-19 Terhadap Proses Pembelajaran Online di Sekolah Dasar. EduPsyCouns: Journal of Education, Psychology and Counseling, 2(1), 1-12. https://ummaspul.ejournal.id/Edupsycouns/article/view/397.

Rachman, A. (2007). Homeschooling rumah kelasku, dunia sekolahku. Jakarta: PT kompas media nusantara.

Rumba, M. F. M. P. . R. T. W. M. (2020). “ New Normal”: Analisis Penerimaan Menggunakan Balance Score Card. Jurnal Riset Teknologi Dan Inovasi Pendidikan, 3(2), 396-402. https://doi.org/https://doi.org/10.36765/jartika.v3i2.303.

Safar, M. P. (2018). A Citical Review Of Homeschooling As Alternative Education In Digital Era. Journal of Muslim Society Research, 3(1), 77-99. http://ejournal.iainpurwokerto.ac.id/index.php/ijtimaiyya/article/view/1675/1 298.

Santoso, S. B. (2010). Sekolah Alternatif Mengapa Tidak? . Yogyakarta: Diva Press.

Saputra, A. A. (2007). Rumahku Sekolahku. Yogyakarta: Graha Pustaka.

Sari, W. A. M. R. M. K. (2020). Analisis Kebijakan Pendidikan Terkait Implementasi Pembelajaran Jarak Jauh Pada Masa Darurat Covid-19. Jurnal Mappesona, 2(1), 113. https://jurnal.iain-bone.ac.id/index.php/mappesona/article/view/830. 
Savitri, A. (2020). Home Schooling Dibandingkan dengan Sekolah Formal. https://pelatihanhomeschooling.com/kelebihan-homeschooling/akses.

Sumardiono. (2007). Homeschooling; Lompatan Cara Belajar. Jakarta: Elex Media Komputindo.

Tuzun, H., Soylu, M. Y., Karakus, T., Inal, Y., \& Kizilkaya, G. (2009). The Effect of Computer games on Primary school students achievement and motivation in Geography Learning. Journal of Computer and Education, 52(1), 68-77. https://doi.org/https://doi.org/10.1016/j.compedu.2008.06.008.

Vlacopoulos, D., \& Makri, A. (2017). The effect of games and simulations on the higher education: a systematic literature review. International Journal of Educational Technology in Higher Education. https://educationaltechnologyjournal.springeropen.com/articles/10.1186/s412 39-017-0062-

1\#: :text=0n\%20balance $\% 2$ C $\% 20$ results\%20indicate $\% 20$ that,cognitive $\% 2 \mathrm{C} \% 2$ Obehavioural\%2C\%20and\%20affective.\&text=Such\%20evidence $\% 20$ also\%20pr ovides\%20potential\%20options $\% 20$ and $\% 20$ pathways $\% 20$ for\%20future $\% 20$ res earch.

Wardati, Z. (2019). Peran Guru Dalam Pembentukan Karakter Sosial Anak Pada Habib Alby Homeschooling. DAYAH: Journal Of Islamic Education, 2(2), 261-280. https://doi.org/http://dx.doi.org/10.22373/jie.v2i2.4185.

WHO. (2020). WHO Coronavirus Disease (COVID-19) Dashboard. Online. Diakses Pada Tanggal 21 Juli 2020.

Zulfi, N. F. (2019). Alasan Orang Tua Memilih Pendidikan Homeschooling Daripada Pendidikan Formal. Universitas Negeri Padang. 